\title{
ANALISIS KRITIS ISI PESAN DAKWAH DALAM BUKU 7 KEAJAIBAN REZEKI
}

\author{
Tantri Junia Hasnah ${ }^{1 *}$, Yaya ${ }^{1}$, \& Aang Ridwan ${ }^{1}$ \\ ${ }^{1}$ Jurusan Komunikasi dan Penyiaran Islam, UIN Sunan Gunung Djati, Bandung \\ *Email : tantrijuniabasnah@gmail.com
}

\begin{abstract}
ABSTRAK
Analisis wacana kritis pada penelitian ini berguna untuk mengetahui orisinilitas buku, menyesuaikan data dan fakta yang dikemukakan penulis, dan memahami latar belakang yang mengiringi terciptanya buku 7 Keajaiban Rezeki, sedangkan metode kualitatif dipilih untuk menalisis konteks pesan dakwah, kontruksi pesan dakwah dan teknik pengemasan pesan dakwah pada buku 7 Keajaiban Rezeki. Dari hasil penelitian tersebut ditemukan bahwa Ippho Santosa berusaha menanamkan kebiasaan sedekah dikalangan masyarakat luas sebagai salahsatu magnet untuk menarik rezeki, meraih kesuksesan, dan meraih kesehatan dalam 99 hari dengan cara berfikir otak kanan karena dilatarbelakangi profesinya sebagai motivator dan pakar otak kanan. Selanjutnya peneitian ini menemukan adanya pesan Akidah, Akhlak, dan syariah dalam Buku 7 Keajaiban Rezeki yang dikontruksikan kedalam 3 jenis pesan yaitu Informatif, Persuasif dan Koersif dengan teknik pengemasan berupa data dan fakta yang sesuai dengan dalil AlQur'an dan kebiasaan yang terjadi di masyarakat. Metode analisis wacana kritis juga menemukan adanya interpretasi pada buku 7 Keajaiban Rezeki yaitu berupa identifikasi wacana teks menjadi proses komunikasi dan adanya Implikasi pada buku 7 Keajaiban Rezeki berupa aspek-aspek kognisi yang dapat diterapkan dikehidupan masyarakat.
\end{abstract}

Kata Kunci: Analisis Kritis; Pesan Dakwah; Media Dakwah.

\section{ABSTRACT}

Critical discourse analysis in this study is useful for knowing the originality of the book, adjusting the date and facts presented by the author, and understanding the background that accompanied the creation of the 7 Keajaiban Rezeki, while the qualitative method was chosen 
to analyze the context of da'wah messages, missionary message construction and da'wah message packeaging techniques. in the book 7 Keajaiban Rezeki. From the results of the study it was found that Ippho Santosa tried to instill alms habits among the general public as one magnet to attract sustenance, acbieve success, and achieve health in 99 days by right-brain thinking because the background was as a motivator and right brain expert. Furthermore, this research found the message of aqeedah, morality, and sharia in the 7 Keajaiban Rezeki Book which was constructed into 3 types of messages, namely Informative, Persuasive and Coercive with packeaging techniques in the form of data and facts in accordance with the Qur'anic propositions and habits that occurred in society. The critical discourse analysis method also found an interpretation in the book 7 Keajaiban Rezeki, namely in the form of identifying text discourse into a communication process and the implication in the book 7 Keajaiban Rereki in the form of cognition aspects that can be applied to people's lives.

Keywords: Critical Analysis; Da'wah message; Da'wah media.

\section{PENDAHULUAN}

Dakwah merupakan kegiatan keagamaan harus dilaksanakan dengan materi, media, dan metode dakwah yang relevan karena termasuk kedalam kegiatan Amar Makruf Nabyi Munkar yang dalam prosesnya melibatkan lebih dari satu orang dan dapat berdampak pada perubahan kehidupan baik pelaku dakwah maupun mad'u dakwah itu sendiri. Maka dari itu, dalam fokus makalah jurnal ini akan membahas mengenai salah satu media dakwah yang relevan, bersifat abadi, dan memiliki rekam jejak yang dapat dilacak yaitu dakwah bil kitabah atau dakwah bil qalam.

Analisis Wacana Kritis ini membahas isi pesan dakwah dalam media karya tulis berupa buku. Buku yang menjadi objek penelitian kali ini berjudul 7 Keajaiban Rezeki karya seorang Trainer Motivator Ippho Santosa, buku ini dikaji dengan menggunakan analisis wacana kritis untuk mengetahui sejauh mana orisinilitas dakwahnya, kesesuaian data dan fakta yang dikemukakan penulis dengan Al-Qur'an dan Hadits, serta mengkaji pengemasan pesan dakwah pada sebuah karya tulis buku untuk dipeljari dan dikembangkan kuantitas pesan dakwahnya serta berguna untuk referensi penulisan buku dakwah kedepan.

Literatur yang diambil pada penelitian ini adalah buku Critical Discourse Analysis (landasan teori, metodologi, dsan penerapan) karya Dr. Haryatmoko yang akan membantu memahami interpretasi sebuah bahasa dari segi penggunaannya. Teori AWK yang diambil adalah teori menurut Teun A. Van Dijk yang menekankan bahwa bahasa dalam sebuah karya tulis tidak sekedar menjadi alat komunikasi, namun juga sering kali digunakan sebagai sarana 
berbagai kepentingan, ${ }^{2}$ maka dari itu penulis tertarik untuk menganalisis buku 7 Keajaiban Rezeki dengan teori AWK teun A. Van Dijk ini. Penelitian Studi Wacana Kritis Teun A. Van Dijk juga menekankan perlu adanya analisis sosial pada karya tulis buku, yang memperhitngkan dimensi linguistik, psikologi pembaca, dan sejarah atau latar belakang yang mengiringi terciptanya buku 7 Keajaiban Rezeki.

Penelitian ini terfokus pada Buku 7 Keajaiban Rezeki yang tergolong kedalam buku Islamic Mitivation. Buku 7 Keajaiban Rezeki ini diterbitkan oleh Kompas Gramedia Building yang beralamat di Jl. Palmerah Barat, No. 29-37, Jakarta 10270 Indonesia. Berikut ini peta kajian, isi dan uraian pada buku 7 Keajaiban rezeki:

Tabel 1. Isi dan Uraian singkat Buku 7 Keajaiban Rezeki

\begin{tabular}{|c|c|}
\hline ISI & URAIAN \\
\hline Jenis Buku & Fiksi, Islamic Motivation Enterpreneurship. \\
\hline Penerbit & PT Elex Media Komputindo \\
\hline Topik Umum & $\begin{array}{l}\text { Metode Percepatan, lompatan, dan keajaiban dengan sentuhan } \\
\text { Islami terkait Keuangan dan Rezeki. }\end{array}$ \\
\hline Aspek Khusus & $\begin{array}{l}\text { Memuat manfaat-manfaat praktis menguasai } 90 \text { persen pintu } \\
\text { rezeki dan memahami } 19 \text { amalan yang melipatgandakan rezeki. }\end{array}$ \\
\hline \multirow{8}{*}{$\begin{array}{l}\text { Tema atau Pokok } \\
\text { Pembahasan }\end{array}$} & Sidik Jari Kemenangan (Lingkar Diri) \\
\hline & Sepasang Bidadari (Lingkar Keluarga) \\
\hline & Golongan Kanan (Lingkar Diri) \\
\hline & Simpul Perdagangan (Lingkar Sesama) \\
\hline & Perisai Langit (Lingkar Diri) \\
\hline & Pembeda Abadi (Lingkar Diri) \\
\hline & Pelangi Ikhtiar (Lingkar Diri \\
\hline & Bonus=Biangnya keajaiban \\
\hline $\begin{array}{l}\text { Teknik dan Struktur } \\
\text { Penyajian }\end{array}$ & $\begin{array}{l}\text { Uraian, Contoh, Hikmah, Poster Motivasi, Stiker Motivasi, } \\
\text { Lagu Motivasi, dan Audio Motivasi durasi } 3 \text { jam. }\end{array}$ \\
\hline Gaya menulis & Eksposisi dan Persuasif. \\
\hline Hal Ihwal Pengarang & $\begin{array}{l}\text { "7 Keajaiban Rezeki" karya seorang pakar otak kanan, } \\
\text { entrepreneurship, penulis mega-bestseller, dan motivator yakni } \\
\text { "Ippho Santosa" }\end{array}$ \\
\hline
\end{tabular}


Buku 7 Keajaiban Rezeki ini ditulis oleh seorang Trainer Motivator dan Enterpreneurship Ippho Santosa sehingga konten yang disajikan dalam buku ini juga berhubungan langsung dengan profesinya tersebut, khalayak juga berpendapat jika satui tulisan dibuat oleh ahlinya maka akan sangat relevan. Itu dapat diartikan bahwa sebuah karya sekalipun akan lebih bernilai harganya apabila dibuat oleh ahlinya.

Meskipun buku 7 Keajaiban Rezeki ini bergenre Islamic Motivation, namun dalam penulisannya Ippho Santosa membahas mengenai Metode sedekah untuk menarik rezeki dan meraih kesuksesan dalam 99 hari dengan metode otak kanan. Pembahasan tentang sedekah jelas merupakan materi keislaman, namun sedekah dalam buku ini dibahas dan duikaitkan dengan metode meraih kesuksesan dengan pendekatan-pendekatan otak kanan sebagai otak percepatan dan kaya akan sentuhan-sentuhan islami seperti hikmah dalam kisah-kisah rasul, bermuatan hadits, dan bermuatan nasehat islami.

Dalam buku "7 Keajaiban Rezeki tersebut" terdapat 7 Bab pembahasan yaitu: 1) Sidik Jari Kemenangan (Lingkar Diri)= segala sesuatu yang unik dalam diri setiap individu yang dengan keunikan itu dapat meraih kemenangan; 2) Sepasang Bidadari (Lingkar Keluarga) $=$ orangtua dan pasangan yang keinginannya harus diselaraskan dengan pribadi kita; 3)Golongan Kanan $($ Lingkar Diri $)=$ meraih rezeki dengan EQ otak kanan, semangat perubahan dan momentum perubahan; 4) Simpul Perdagangan (Lingkar Sesama) = cara meraih rezeki dengan hubungan sesama, cara terbaik menggerakan uang, kaya bukan madharat, cara dakwah Nabi yang alami, Islam Agama yang menyuruh kaya, boleh miskin? (tidak), berdagang pekerjaan yang dianjurkan Al-Qur'an, kaitkan dengan Sepasang Bidadari; 5)Perisai Langit (Lingkar Diri) $=$ pahami diri sendiri, pahami musuh, pamrih? (Boleh), Tidak Ikhlas? (Boleh), Sedekah; 6) Pembeda Abadi (Lingkar Diri) $=$ kemampuan, persepsi publik, tingkatkan kekuatan, tinggalkan kelemahan; 7) Pelangi Ikhtiar (Lingkar Diri) $=$ selaraskan ikhlas, ikhtiar, dan integritas; 8) Bonus=Biangnya keajaiban ${ }^{3}$

Dalam 7 bab tersebut terdapat lingkar diri, lingkar keluarga, lingkar sesama, lingkar semesta dan lingkar pencipta. Lingkar-lingkar tersebut menjadi gambaran 7 keajaiban rezeki tersebut dapat diraih melalui salah satu lingkar yang paling cocok. Poin dari lingkar-lingkar tersebut adalah kalau anda berhasil menggenggam erat-erat lingkar yang pertama, maka dengan sendirinya anda akan berhasil menyentuh dua lingkar selanjutnya yang jauh lebih besar. Namun, hukum sebalikya juga berlaku sepenuhnya. Kalau anda mengabaikan Lingkar

\footnotetext{
${ }^{3}$ Ippho Santosa. (2012). 7 Keajaiban Rezeki, Rezeki Bertambah, Nasib Berubah, Dalam 99 Hari dengan Otak Kanan, PT. Alex Media Komputindo, Kelompok Gramedia, Cetakan ke-21.
} 
Diri, Lingkar Keluarga, dan Lingkar Sesama, maka anda akan betul-betul terasing dari Lingkar Semesta dan Lingkar Pencipta, dalam artian semesta dan penciptapun tidak akan memudahkan urusan dan rezeki anda apabila anda mengabaikan keluarga dan sesama.

Berdasarkan teori yang digunakan dan lokasi penelitian yang dipilih maka ditemukan fokus penelitian yang berfungsi sebagai pemusatan konsentrasi terhadap tujuan penelitian. Maka rumusan masalah pada karya tulis ini adalah, Bagaimana isi pesan dakwah dalam buku 7 Keajaiban Rezeke? Bagaimana konstruksi pesan dakwah dalam buku 7 Keajaiban Rereker? Bagaimana pengemasan pesan dakwah dalam buku 7 Keajaiban Rezeke??

\section{LANDASAN TEORITIS}

\section{Hakikat Dakwah Bil Qalam}

Hakikat dakwah bil qalam secara sosiologis adalah memberikan informasi secara jelas kepada seluruh manusia bahwa dakwah bukan hanya sekedar menyampaikan materi keislaman saja, lebih jauh lagi dakwah adalah kegiatan untuk melakukan upaya perubahan pada kehidupan manusia ke arah yang lebih baik lagi yaitu menjadi masyarakat yang madani dan islami. ${ }^{4}$ Sedangkan ditinjau dari segi bahasa, dakwah berarti mangajak, menyeru untuk mempercayai, memahami, mengimani dan mengamalkan ajaran-ajaran islam atau yang biasa kita sebut dengan materi dakwah. ${ }^{5}$ Dalam upaya penyampaian materi dakwah tersebut, hendaknya menggunakan metode yang relevan yang dalam makalah jurnal ini terfokus pada metode dakwah bil kitabah atau yang lazim disebut dakwah bil qalam.

Dakwah bil qalam dengan media tulisan ini telah ada sejak zaman rasul dan menjadi salah satu media dakwah yang paling tua. Terfokus pada pengadaan materi dakwah yang efisien, praktis, relevan dan memiliki rekam jejak yang akurat serta dapat dipercaya, dakwah bil qalam selalu relevan dan terus mengalami pembaharuan mengikuti perkembangan zaman serta tidak pernah mengalami naik turun popularitas. Namun yang harus menjadi perhatian para praktisi dakwah dalam mengaplikasikan dakwah bil qalam ini adalah harus memiliki kemampuan dalam menulis naskah dakwah. ${ }^{6}$ Kemampuan inilah yang akan membawa tulisan dakwah menjadi menarik untuk dibaca, diantara hal-hal yang harus diperhatikan dalam menulis naskah dakwah adalah menentukan konten dakwah yang sesuai dengan segmentasi pembaca, menyediakan reverensi

\footnotetext{
${ }^{4}$ Acep Aripudin. (2013). Sosiologi Dakwah, Bandung: Rosdakarya. Hal.13.

${ }^{5}$ A. Subandi dan Syukriadi Sambas, (1999). Dasar-dasar Bimbingan. Jakarta: Amzah. Hal.5.

${ }^{6}$ Aep Kusnawan. (2016). Teknik Menulis Naskah Dakwah. Bandung: Simbiosa Rekatama Media. ISBN 978-602-7973-44-2. Hal 18.
} 
yang akurat, dan kemampuan menyusun kalimat menjadi sebuah proses komunikasi pada tulisan.

\section{Bentuk-Bentuk Dakwah Bil Qalam}

Modifikasi pada dakwah bil qalam terus mengalami kemajuan sehingga dapat dinikmati oleh semua kalangan dari mulai kalangan masyarakat umum, akademisi, hingga praktisi dakwah itu sendiri. Tahap modifikasi pada dakwah bil qalam terbagi menjadi dua bentuk yaitu klasik dan kontemporer. Media dakwah bil qalam klasik merujuk pada pembukuan dan media cetak seperti buku, majalah, koran, artikel, opini, cerpen, maka sudah menjadi kewajiban bagi para praktisi dakwah untuk menjajal peluang dakwah memalui media cetak dan media massa cetak sehingga para praktisi dakwah dapat mengisi kolom-kolom di media cetak dan media massa tersebut. ${ }^{7}$

Selanjutnya media dakwah bil qalam dalam bentuk kontemporer yaitu dakwah bil qalam memasuki era internet dan teknologi, dipelopori oleh media Blog materi dakwah bisa diakses kapanpun dan dimanapun dengan adanya koneksi internet, materi dakwah yang disajikanpun lebih beragam dengan konten-konten yang lebih kreatif, hal tersebut dilakukan untuk memenuhi kebutuhan para kaula muda yang lebih banyak mengakses konten dakwah memalui blog ini. Selain melalui blog, dakwah bil qalam era kontemporer dapat juga dilakukan dengan mengisi kolom-kolom status pada sosial media dalam bentuk fanpage. Diantara beberapa praktisi dakwah kondang yang telah melakukan dakwah melalui media kontemporer ini adalah ustad Gymnastiar, Yusuf Mansyur, dan Ustad Abdul Somad. Maka dari itu, para praktisi dakwah di era kontemporer ini harus memiliki kemampuan mengakses internet, berkomunikasi melalui media sosial, dan mengikuti segala macam perkembangan teknologi, dengan begitu dakwah bil qalam dapat terus mengalami kemajuan. ${ }^{8}$

Secara keseluruhan baik bentuknya klasik atau kontemporer, cetak atau elektronik, media dakwah bil qalam ini harus mampu menonjolkan karakteristiksisi kedakwahan atau terfokus pada penanaman nilai-nilai keislaman karena objek yang dituliskan adalah mengajak kepada kebaikan dan mencegah kepada kemunkaran atau biasa kita sebut dengan Amar Makruf Nahyi Munkar. Jalaluddin Rajhmat mengemukakan ada dua bahan pertimbangan yang menjadi acuan utama para pendakwah dalam optimalisasi penggunaan media tulisan, yaitu harus memperhatikan struktur pesan yang disampaikan dan kategorisasi pesan harus dipilih berdasarkan segmentasi pembaca. Segmentasi pembaca dipilah

\footnotetext{
${ }^{7}$ Aep Kusnawan, (2009). Creative Writing Club Sistem Swa-Mandiri Pelatihan Menulis. Jurnal Ilmu Dakwah, Vol.4, No.13, Januari-Juni, hal.596.

${ }^{8}$ Dr. Moch. Fachruroji. (2017). Dakwah di Era Media Baru. Bandung: Simbiosa Rekatama Media. Hal.10.
} 
berdasarkan suku, bangsa, ras, agama, usia, pekerjaan, dan jenis kelamin, hal tersebut dilakukan agar dakwah bil qalam dapat diterima oleh seluruh lapisan masyarakat sesuai dengan kebutuhan masyarakat itu sendiri.

\section{Teori Analisis Wacana Kritis}

Analisis Wacana kritis (Critical Discourse Analysis) pada penelitian ini menggunakan teori yang dikemukakan oleh Teun A. Van Dijk yaitu untuk mengetahui struktur mikro dan makro pada sebuah karya tulis buku yang bertujuan untuk menafsirkan pesan-pesan simbolik dan komuniksi yang disampaikan dalam sebuah karya tulis buku, struktur mikro dan makro inilah yang nantinya akan diteliti secara kualitatif untuk mencari seperangkat tema pokok dari sebuah tulisan dan selanjutnya dikaji untuk diteliti dari segi kuantitas pesan dakwah, kontruksi pesan dakwah dan teknik pengemasan pesan dakwah pada sebuah karya tulis buku yang dalam penelitian ini terdapat dalam buku 7 Keajaiban Rezeki karya Ippho Santosa.

Analisis Wacana kritis ini juga berusaha mengungkapkan bahwa sebuah teks pada karya tulis dapat digunakan untuk beragam fungsi dan mempunyai beragam konsekuensi, fungsi lain dari adanya tulisan menurut AWK selain untuk menyampaikan sesuatu, juga berfungsi untuk memerintah, mempengaruhi, mendeskripsi, mnegiba, membujuk, dan memanipulasi. ${ }^{9}$ Maka media dakwah melalui tulisan ini dianggap cocok untuk menyampaikan pesan (informatif), mengajak (persuasif), dan mempengaruhi/memaksa (koersif) namun tetap dilakukan dengan cara yang santun dan disertai dengan sebab-akibat. Jadi studi wacana kritis bukan sekedar penelitian sosio-politik pada sebuah tulisan, namun lebih terfokus pada premis bahwa ada beberapa bentuk teks dan wicara yang bisa saja memiliki maksud tertentu, bisa baik atau buruk, bisa adil atau tidak adil, maka AWK berusaha menemukan maksud utama dari tulisan tersebut. ${ }^{10}$ Dalam penelitian ini AWK berusaha mencari kemurnian pesan dakwah pada buku 7 Keajaiban Rezeki, kontruksi pesan dakwah pada buku 7 Keajaiban Rezeki, dan teknik pengemasan pesan dakwah dalam buku 7 Keajaiban Rezeki.

\section{Prinsip Teori Analisis Wacana Kritis}

Prinsip dasar dalam melakukan penelitian menggunakan Analisis Wacana Kritis terdiri dari sepuluh tahapan yaitu, 1) Teks dan pembahasan dalam tulisan benerbenar terjadi dan bukan rekayasa, 2) Ada konteks/tema yang dibahas, 3) Tema tulisan mampu menjadi teks komunikasi, 4) Tulisan dapat menjadi praktek sosial bagi pembaca, 5) tulisan tidak menyinggung suku, ras, agama pembaca, 6)

\footnotetext{
${ }^{9}$ Van, Dijk Teun. A. 1993. Principles of Critical Discourse Analysis. Discourse and Society.

${ }^{10}$ Haryatmoko. (2017). Critical Discourse Analysis (Analisis Wacana Kritis) Landasan Teori, Metodologi, dan Penerapan. Jakarta: Raja Grafindo, hal.77-78.
}

Tabligh: Jurnal Komunikasi dan Penyiaran Islam Vol. 4 No. 2 (2019) 145-166 
Pembahasan berurutan, 7) Aspek kontruktivitas, 8) ada tingkatan dan dimensi, 9) Ada Makna dan fungsi pada tulisan, 10) Mematuhi kaidah dan aturan bahasa, 11) Ada strategi komunikasi yang digunakan, dan 12) mengandung kognisi sosial yang bermanfaat bagi masyarakat. Jadi Analisis Wacana Kritis bergerak dari struktur makro ke struktur mikro dan membutuhkan alat teoritis dan metodologis untuk mempertajam analisis kritis ini. ${ }^{11}$

Selanjutnya langkah-langkah penelitian menggunakan Analisis Wacana Kritis adalah:

1. Menganalisis konteks berupa setting tempat, waktu dan situasi partisipan.

2. Pencarian makna makrostruktur semantik untuk mengetahui topik dan tema global.

3. Mencari gramatika, semantik, dan fonetik melalui pemaknaan lokal.

4. Mencari relevansi struktur formal yang tersamar pada tulisan.

5. Menganalisis model konteks yang menghubungkan teks dengan konteks.

6. Menginterpretasikan model peristiwa pada konsep dan proposisi bacaan.

7. Mencari kognisi sosial berupa pembahasan yang berpengaruh bagi situasi masyarakat.

8. Mencari tindakan yang dianggap diskursif pada tulisan yang berperan sebagai tindakan sosio-politik.

9. Memahami struktur masyarakat sebagai segmentasi pembaca. ${ }^{12}$

Pada dasarnya studi wacana kritis tertarik menganalisis peran suatu teks bacaan pada buku yang mampu menggiring pemahaman masyarakat pada ideologi tertentu, untuk mengikuti ideologi tersebut. Studi Wacana Kritis menjadi salahsatu teori yang dapat digunakan untuk menjembatani pemikiran masyarakat untuk lebih kritis terhadap berbagai sumber bacaan, relevansinya dengan buku 7 Keajaiban Rezeki teori ini mencoba menggali polemik dan mencari kesesuaian buku dengan ilmu dakwah dan mengajak pembaca untuk mendiskusikan masalah atau fenomena yang terdapat dalam buku 7 Keajaiban Rezeki. ${ }^{13}$

\section{HASIL DAN PEMBAHASAN}

\section{Pesan-pesan Dakwah dalam Buku 7 Keajaiban Rezeki}

\section{Pesan Akidah}

Pesan akidah terdapat pada posisi pertama, hal tersebut dilandasi bahwa buku 7 Keajaiban Rezeki ini adalah metode percepatan-percepatan terkait keuangan, kesehatan, impian, prestasi, hubungan, jodoh, dll, yang secara keseluruhan

\footnotetext{
${ }^{11}$ Ibid, Hal.81.

${ }^{12}$ Ibid, hal.84-90.

${ }^{13}$ Ibid, hal.90. 
melibatkan aspek kehidupan yang tidak bisa dijangkau secara kasat mata, semuanya berhubungan dengan Allah langsung sebagai yang maha tahu, lagi maha kuasa. Berhubungan langsung dengan rukun iman karena aspek kehidupan seluruhnya terdapat dalam Al-Qur'an, dan As-Sunnah yang berarti kita mempercayai keberadaan Nabi dan para Rasul serta bekaitan erat dengan ikhtiar merubah takdir yang masih bisa dirubah dan meraih takdir Allah yang mutlak dengan jalan yang baik.

Dengan adanya pesan pesan akidah ini diharapkan, penulis dapat mengajak pembaca kepada jalan keislaman yang beriman dengan bekal ilmu yang baik agar seluruh aspek kehidupan yang kita inginkan dapat kita capai dengan cara yang baik pula.

\section{Pesan Syariah}

Pesan syariah terdapat pada posisi kedua, karena pada dasarnya kebermanfaatan dari buku ini hanya akan terasa apabila kita memprakteknnya, maka pesan syariah yang berisi ibadah dan muamalah merupakan dua pendamping pokok dari aksi kita dalam mengamalkan isi buku 7 Keajaiban Rezeki ini.

Usaha harus tetap dibarengi dengan ibadah dan doa, serta kita wajib berbuat baik dilingkungan kita supaya lengkap sebagai suatu kesatuan yang utuh yakni, Doa (Ibadah), Ikhtiar (Usaha), dan tawakal, dan do'a itu akan sangat terbantu jika sifat kita terhadap unsur muamalahnya baik, maka orang lain disekeliling kitapun akan turut mendoakan yang terbaik bagi kita.

\section{Pesan Akhlak}

Pesan akhlak terdapat pada urutan nomor 3, penerapannya adalah akhlak terhadap Allah, akhlak terhadap sesama dan akhlak terhadap lingkungan. Dalam buku 7 Keajaiban Rezeki, pesan akhlak banyak memuat bagaimana kita harus bersikap dan berprilaku, karena tidak akan menjadi orang yang sukses dan berhasil apabila tidak berprilaku baik kepada Allah, Sesama dan lingkungan.

Patut disadari bahwa ketiga elemen Akhlak ini semuanya saling berkaitan. Ridha Allah tergantung Ridha orangtua, maka ridha orangtua termasuk kewajiban kita untuk berakhlak baik kepada orangtua agar mendapatkan ridha dari Allah. Begitupun dengan lingkungan, lingkungan sebagai faktor pendukung keberhasilan kita harus kita juruskan menjadi lingkungan yang positif dan memberikan pengaruh positif.

\section{Kontruksi Pesan Dakwah dalam Buku 7 Keajaiban Rezeki}

\section{Lingkar diri:}

a. Sidik Jari Kemenangan : Cara meraih kemenangan.

b. Golongan Kanan : Semangat Perubahan, momentum perubahan. 
T. J. Hasnah, Yaya, A. Ridwan

c. Perisai Langit : Pahami diri sendiri, pahami musuh, pamrih (boleh), tidak ikhlas (boleh), sedekah.

d. Pembeda Abadi : Kemampuan, persepsi, tingkat kekuatan, tingkat kekurangan.

e. Pelangi ikhtiar : Ikhlas, ikhtiar, integritas.

\section{Lingkar Keluarga:}

Sepasang bidadari : menyelaraskan keinginan orangtua dan pasangan dengan kita.

\section{Lingkar Sesama:}

Simpul Perdagangan : Cara terbaik menggerakan uang, kaya manfaat, kaya bukan madharat, cara dakwah Nabi yang alami, Islam agama yang menyuruh kaya, boleh miskin? (TIDAK), berdagang adalah pekerjaan yang dianjurkan AlQur'an, kaitkan dengan sepasang bidadari.

Analisis tentang struktur pesan dakwah dalam buku 7 Keajaiban Rezeki menggunakan tiga bentuk Pesan dakwah, seperti yang dikemukakan oleh A.W. Widjaja dan M. Arisyk Wahab, yaitu:

\section{a. Informatif}

Pesan Informatif ini digunakan untuk menstrukturkan pesan dakwah menggunakan fakta dan data sehingga pembaca dapat mengambil kesimpulan dari isi pesan dakwah dalam bacaan. Dalam buku 7 Keajaiban Rezeki, pesan dakwah informatifnya meliputi:

1) "Dakwah itu harus sesuai dengan bahasa kaumnya, seperti ketika para nabi dan rasul diutus untuk berdakwah dengan bahasa dan keadaan kaumnya". (Halaman 76, Paragraph 4)

2) Dalam Bab Simpul Perdagangan, penulis berkesimpulan "Berdagang; Pekerjaan yang dianjurkan dalam Al-Qur'an" yang dilengkapi fakta ayat-ayat Al-Qur'an.

3) "Bisnis yang membuat kaya: Bisnis yang melayani Jutaan dan Ribuan Orang" kalimat tersebut didukung fakta dengan objek salah satu Agen Travel Haji dan Umrah sebagai contohnya.

4) Hasil riset yang dituangkan kedalam buku 7 Keajaiban Rezeki mengenai kunci sukses dengan, Kiri (IQ); Kognitif, Realistis, Matematis, Eksplisit, dan Self Centric. Kanan (EQ); Efektif, Empati, Luwes, Implisit dan other-centric. Berdasarkan hasil Riset, sukses itu memerlukan 80\% EQ dan 20\% IQ. 


\section{b. Persuasif}

Pesan Persuasif ini digunakan untuk membujuk dan membangkitkan kesadaran serta untuk meyakinkan bahwa apa yang disampaikan dalam buku 7 Keajaiban Rezeki dapat memberikan manfaat bagi pembaca. Namun manfaat itu hanya akan terasa apabila pembaca berusaha mempraktikan isi buku 7 Keajaiban Rezeki. Dalam buku 7 Keajaiban Rezeki, pesan persuasif meliputi:

1) "Sampaikanlah walau satu ayat (Walau banya 1 bagian dari buku ini)" halaman 91, nomor 8. Penulis mengajak pembaca untuk membagikan manfaat buku ini.

2) "Orang Miskin wajib sedekah" halaman 101. Penulis bermaksud mematahkan argumen bahwa orang miskin tidak wajib sedekah dan mengajak orang miskin untuk ikut bersedekah agar mendapatkan keutamaan-keutamaan sedekah itu, karena pahala Allah tidak pernah memandang status.

3) "Iika anda ingin seorang istri, karena istri tidak bisa diitung harganya, tidak bisa disedekabkan harta kita sebanyak 10\%. Untuk hal itu, maka sedekabkan harta yang paling anda cintai" halaman 105. Penulis mengajak apabila ada hal yang kita inginkan maka kita harus menjemputnya atau mengikhtiarkannya dengan sedekah.

4) "Kreativitas itu bukan banya tentang bal yang aneh-aneh, tapi kreativitas itu meliputi semangat perubahan", Penulis mengajak kepada para pembaca untuk senantiasa semangat dalam hal perubahan ke arah yang lebih baik.

5) Dalam momentum bagian-bagian perubahan, halaman 76 "Hal-hal yang akan mendorong kita menjadi lebih baik saat usaha kita untuk. berubah dengan cara lain belum berhasil'. Penulis menghimbau agar kita jangan mudah menyerah apabila dihadapkan pada kegagalan dalam sebuah perjalanan menuju keberhasilan, maka kita harus terus mencari jalan lain untuk mencapainya.

6) "Beritabu manfaat otak kanan kepada orang lain, kirim pesan informasi untuk. buku ini, pinjamkan buku ini kepada orang lain, dan bergabung di Fanpage Facebook 7 Keajaiban Rezeke?", penulis mengajak agar buku 7 keajaiban Rezeki ini bsnysk bermanfaat, dan pahalanya akan terus mengalir ke kita, maka pinjamkanlah buku ini, dan ceritakan bagaimana anda sukses menggunakan buku ini.

\section{c. Koersif}

Pesan Koersif ini digunakan untuk memaksa pembaca mengikuti buku ini dengan menggunakan sanksi-sanksi untuk menimbulkan pengesanan dan 
T. J. Hasnah, Yaya, A. Ridwan

ketakutan publik. Dalam buku 7 Keajaiban Rezeki ini terdapat pesan koersif, diantaranya:

1) "Ikhlas atau tidak ikhlas tetap dibalas!" Balasan jangka pendek (Dunia) dan Balasan jangka panjang (Akhirat).

2) "Pamrih? Boleh!" asal pamrihnya sama Allah yang menjamin balasan dari setiap amal kita. Halaman 99.

\section{Teknik Pengemasan Pesan Dakwah dalam Buku 7 Keajaiban Rezeki}

Dalam pengemasan pesan dakwahnya, buku 7 Keajaiban Rezeki, menggunakan pedoman 3 kategori:

Tabel 2. Kategorisasi Pesan Dakwah dalam Buku 7 Keajaiban Rezeki

\begin{tabular}{lll}
\hline NO & KATEGORI & SUB KATEGORI \\
\hline 1 & Pesan Akidah & Iman kepada kepada Allah \\
& Iman kepada malaikat Allah \\
& Iman kepada kitab Allah \\
& Iman kepada Rasul Allah \\
& Iman kepada Hari Akhir \\
& Iman kepada Qadha dan Qadhar \\
& Pesan Akhlak & Akhlak kepada Allah \\
& & Akhlak kepada Manusia \\
& & Akhlak kepada Lingkungan \\
\hline 3 & Pesan Syariah & Ibadah \\
& & Muamalah (Kehidupan sosial) \\
\hline
\end{tabular}
Rezeki, dapat dilihat dari kalimat serta dialog yang dilakukan tahapan analisis secara detail.

\section{a. Pesan Akidah}

Pesan dakwah dalam buku 7 Keajaiban Rezeki yang mengandung kategori Akidah, yaitu:

\section{1) Iman Kepada Allah}

Dasar hukumnya terdapat dalam QS. Al-Baqarah ayat 186:

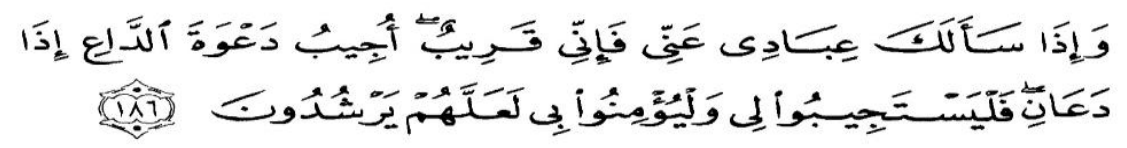


"Dan apabila hamba-hamba-Ku bertanya kepadamu tentang Aku, maka (jawablah), bahwasanya Aku adalah dekat. Aku mengabulkan permohonan orang yang berdoa apabila ia memohon kepada-Ku, maka hendaklah mereka itu memenuhi (segala perintah-Ku) dan hendaklah mereka beriman kepada-Ku, agar mereka selalu berada dalam kebenaran." (Kementerian Agama Republik Indonesia, Al-Qur'an Terjemahan, Mushaf Al-Tasdiiq. Bandung: Tasdiqiya Publisher : 2010).

Pesan iman kepada Allah dalam Buku 7 Keajaiban Rezeki terdapat pada kalimat-kalimat sebagai berikut "Bukankah Dia yang telah menghadirkan kita ke muka bumi ini? Pastilah Dia yang akan bertanggungjawab untuk mencukupkan rezeki kita" (halaman 48).

Dalam kalimat tersebut penulis menegaskan bahwa kita sebagai makhluk tidak perlu merasa khawatir akan rezeki, bahkan secara eksternal dapat dikatakan "Penghinaan terbadap Tuban itu bukan banya musyrik dan murtad saja. Kita takut tidak. makan pun sudah sangat menghina Tuban".

"Soal rezeki, memang sampai kapanpun matematika manusia tidak akan sanggup menyamai matematika Tuban" (halaman 48). Dalam kalimat tersebut, menegaskan bahwa kita tidak perlu takutkekurangan karena rezeki Allah untuk makhluknya tidak dapat diitung secara matematik.

"Tuban sendiri mempunyai sifat Maha Kaya (Al-Ghani) dan maha Mengayakan. Nah sebagai hamba-nya manusia diwajibkean meniru sifat-sifat-Nya" (halaman 78). Dalam kalimat yang memerintahkan kita untuk mengikuti sifat Allah tersebut juga tersirat penegasan akan sifat Allah itu sendiri dan kita wajib untuk mengimaninya.

\section{2) Iman Kepada Malaikat Allah}

Dasar Hukumnya terdapat dalam QS. Al-Hasyr ayat 7:

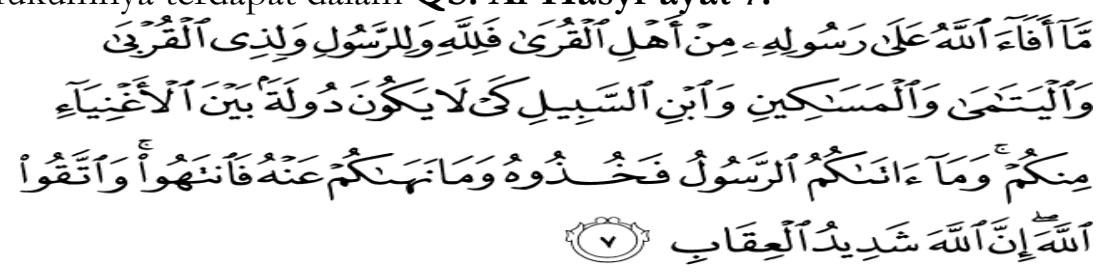

"Apa saja harta rampasan (fai-i) yang diberikan Allah kepada Rasul-Nya (dari harta benda) yang berasal dari penduduk kota-kota maka adalah untuk Allah, untuk Rasul, kaum kerabat, anak-anak yatim, orang-orang miskin dan orang-orang yang dalam perjalanan, supaya harta itu jangan beredar di antara orang-orang kaya saja di antara kamu. Apa yang diberikan Rasul kepadamu, maka terimalah. Dan apa yang dilarangnya bagimu, maka tinggalkanlah. Dan bertakwalah kepada Allah. Sesungguhnya Allah amat keras hukumannya." (Kementerian Agama 
T. J. Hasnah, Yaya, A. Ridwan

Republik Indonesia, Al-Qur'an Terjemahan, Mushaf Al-Tasdiiq. Bandung: Tasdiqiya Publisher : 2010).

Pesan iman kepada Malaikat dalam Buku 7 Keajaiban Rezeki terdapat pada kalimat-kalimat sebagai berikut "Malaikatpun diatur dengan kekuasaan".

\section{3) Iman Kepada Kitab Allah}

Dasar hukumnya terdapat dalam QS. Al-Baqarah Ayat 2:

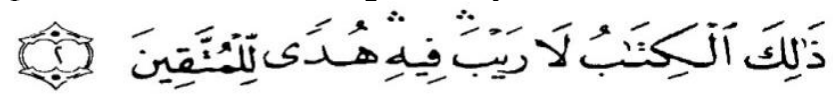

'Kitab (Al Quran) ini tidak ada keraguan padanya; petunjuk bagi mereka yang bertakwa," (Kementerian Agama Republik Indonesia, Al-Qur'an

Terjemahan, Mushaf Al-Tasdiiq. Bandung: Tasdiqiya Publisher : 2010)

Pesan iman kepada Kitab Allah dalam Buku 7 Keajaiban Rezeki terdapat pada kalimat-kalimat sebagai berikut:

"Isra Miraj dan turunnya perintah Shalat dalam Al-Qur'an”. Dalam kalimat tersebut, penulis menjelaskan bahwa mutlak Al-Qur'an itu adalah pedoman hidup karena didalamnya memuat salah satu rukun Islam, yaitu shalat.

"Kalaupun ada sesuatu yang ia tinggalkan, itu adalah Al-Qur'an satu-satunya kitab suci di dunia yang bisa dihafal, satu-satunya kitab suci yang masih otentik, dan satu-satunya kitab suci yang hanya tersedia di satu versi" (halaman 81). Dalam kalimat tersebut dijelaskan berbagai keistimewaan Al-Qur'an sebagai kitab suci yang wajib kita imani.

\section{4) Iman Kepada Rasul Allah}

Dasar hukumnya terdapat dalam QS. An-Nisa ayat 80:

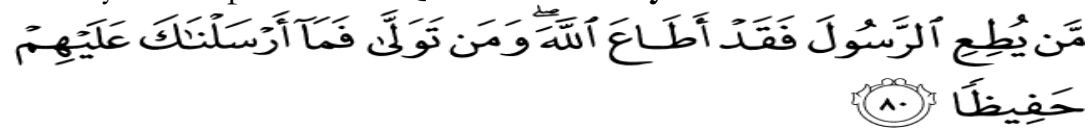

"Barangsiapa yang mentaati Rasul itu, sesungguhnya ia telah mentaati Allah. Dan barangsiapa yang berpaling (dari ketaatan itu), maka Kami tidak mengutusmu untuk menjadi pemelihara bagi mereka." (Kementerian Agama Republik Indonesia, Al-Qur'an Terjemahan, Mushaf Al-Tasdiiq. Bandung: Tasdiqiya Publisher : 2010).

Pesan iman kepada Rasul Allah dalam Buku 7 Keajaiban Rezeki terdapat pada kalimat-kalimat sebagai berikut:

"Turunnya wabyu pertama dan diangkatnya Mubammad menjadi nabi"

"Tiba-tiba saya teringat pesan Nabi Mubammad siapa menyeru kepada kebaikan, maka ia mendapat pahala sebagaimana pabala orang yang mengerjakannya, tanpa mengurangi pahala mereka sedikitpun' yap, inilah amal jariyab” (halaman 74)

Dalam 2 kalimat diatas menjelaskan beberapa sejarah penting umat Islam yang juga patut dijadikan suritauladan. 


\section{5) Iman Kepada Hari Akhir}

Dasar hukumnya terdapat dalam QS. Az-Zumar ayat 68:

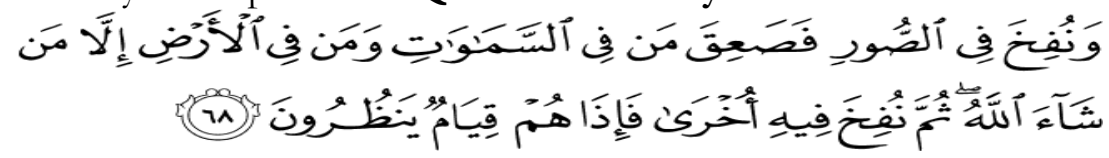

"Dan ditiuplah sangkakala, maka matilah siapa yang di langit dan di bumi kecuali siapa yang dikehendaki Allah. Kemudian ditiup sangkakala itu sekali lagi maka tiba-tiba mereka berdiri menunggu (putusannya masingmasing).” (Kementerian Agama Republik Indonesia, Al-Qur'an Terjemahan, Mushaf Al-Tasdiiq. Bandung: Tasdiqiya Publisher : 2010)

Pesan iman kepada Hari Akhir dalam Buku 7 Keajaiban Rezeki terdapat pada kalimat-kalimat sebagai berikut:

"Di akhir zaman, kaumnya sangat mengagungkan perdagangan. Yaa, perdagangan adalah 'bahasa' mereka. Maka mereka, kepada kaum tersebut diutuslah seseorang yang mampu menguasai perdagangan, namanya Mubammad" (halaman 76)

"Umat akhir zaman, mulai dari masyarakat Quraisy zaman dulu sampai masyarakat zaman sekarang amat mengagungkan para pedagang" (halaman 77)

Dalam 2 kalimat diatas penulis cukup lugas menyebutkan kata "Akhir zaman", itu berarti penulis seolah menjelaskan latar belakang historis yang menunjukan buku ini relevan untuk dijadikan rujukan.

\section{6) Iman Kepada Qadha dan Qadhar}

Dasar hukumnya terdapat dalam QS. Ali Imran ayat 145:

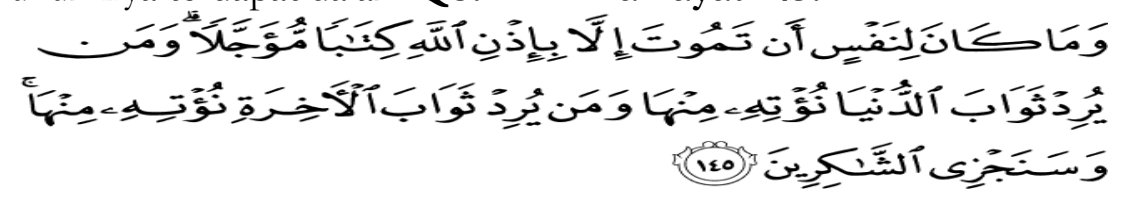

"Sesuatu yang bernyawa tidak akan mati melainkan dengan izin Allah, sebagai ketetapan yang telah ditentukan waktunya. Barang siapa menghendaki pahala dunia, niscaya Kami berikan kepadanya pahala dunia itu, dan barang siapa menghendaki pahala akhirat, Kami berikan (pula) kepadanya pahala akhirat itu. Dan kami akan memberi balasan kepada orang-orang yang bersyukur." (Kementerian Agama Republik Indonesia, Al-Qur'an Terjemahan, Mushaf Al-Tasdiiq. Bandung: Tasdiqiya Publisher :2010).

Pesan iman kepada Qadha dan Qadhar dalam Buku 7 Keajaiban Rezeki terdapat pada kalimat-kalimat sebagai berikut

"Begitu beranjak remaja dan dewasa, barulah ia menyadari kelemahankelemahan dirinya. Ia pun berniat, berhasrat, dan bertekad untuk berubah, 
dari pecundang menjadi pemenang. Berkat pertolongan sang maha kuasa dan sepasang bidadari, ia berhasil mengubah nasibnya" (halaman 27).

Dalam kalimat tersebut penulis berpesan agar kita senantiasa mendengarkan apa yang dikatakan orangtua (Sepasang bidadari) dan juga senantiasa bertakwa kepada Allah SWT karena keduanya berperan penting dalam masa depan dan kehidupan kita.

"Jika anda memiliki impian, jika anda serius ingin mewnjudkannya, maka salah satu syaratnya anda harus menetapkan kapan itu akan terjadi" (halaman 40). Dalam kalimat tersebut menjelaskan bahwa setiap takdir kehidupan manusia sudah digariskan, namun ada takdir kehidupan yang masih bisa kita ubah dan kita ikhtiarkan dengan usaha.

\section{b. Pesan Akhlak}

\section{1) Akhlak Kepada Allah}

Dasar hukumnya terdapat dalam QS. Al-‘an'am ayat 162:
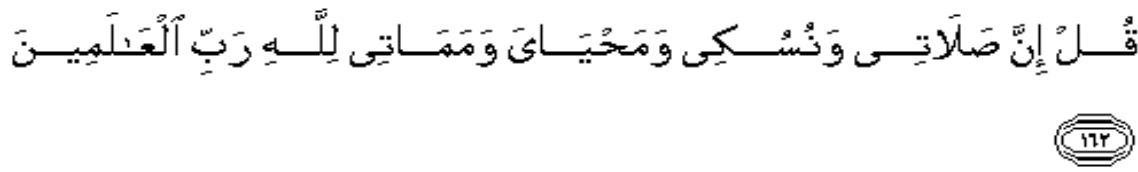

"Katakanlah: sesungguhnya sembahyangku, ibadatku, hidupku dan matiku hanyalah untuk Allah, Tuhan semesta alam." (Kementerian Agama Republik Indonesia, Al-Qur'an Terjemahan, Mushaf Al-Tasdiiq. Bandung: Tasdiqiya Publisher : 2010)

Pesan akhlak kepada Allah dalam Buku 7 Keajaiban Rezeki terdapat pada kalimat-kalimat sebagai berikut "Bersynkur, Khusnudzan, Istigfar, dan Drikir itu mesti diamalkan kapanpun, dan tidake harus ada sebab-sebab khusus juga tidak harus dalam bitungan-hitungan khusus" (halaman 61). Kalimat diatas menjelaskan apa yang harus menjadi rutinitas kita sehari-hari sebagai bentuk akhlak yang baik kita terhadap Allah SWT.

"Allah SWT lebih menyukai muslim yang kuat iman dan nafkahnya daripada muslim yang lemab" (halaman 79). Akhlak kita sebagai manusia selanjutnya adalah senantiasa kuat akan segala cobaan, namun harus senantiasa merasa kecil dihadapan Allah SWT.

"Dan memang kita disurub pamrih, berbarap dan meminta kepada-Nya, babkan meminta kepadanya dicatat sebagai Ibadah" (halaman 99). Akhlak terhadap Allah yang selanjutnya dari buku ini adalah senantiasa berharap dan bergantung hanya kepada Allah sebagai bentuk ketaatan kita, dan memang hanya Allah lah sebaikbaiknya tempat mengadu dan berharap. 


\section{2) Akhlak Kepada Manusia}

Dasar hukumnya terdapat dalam QS. Ali Imran ayat 134:

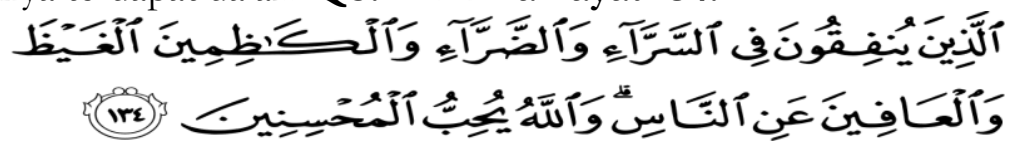

"(yaitu) orang-orang yang menafkahkan (hartanya), baik di waktu lapang maupun sempit, dan orang-orang yang menahan amarahnya dan memaafkan (kesalahan) orang. Allah menyukai orang-orang yang berbuat kebajikan.” (Kementerian Agama Republik Indonesia, Al-Qur'an Terjemahan, Mushaf Al-Tasdiiq. Bandung: Tasdiqiya Publisher : 2010).

Pesan akahlak kepada manusia dalam Buku 7 Keajaiban Rezeki terdapat pada kalimat-kalimat sebagai berikut

"Yang namanya berbakti kepada orangtua tidak akan pernah berakhir dengan sia-sia. Apabila anda berhasil membuat sepasang bidadari tersenyum, pastilah yang Maha Membalas serta merta akan mengulurkan tangan-Nya untuk anda" (halaman 20).

Akhlak terhadap sesama manusia yang pertama dalam buku ini adalah akhlak terhadap orangtua, yang dicontohkan dengan kita harus senantiasa membahagiakan orangtua sebagai jalan mendapatkan ridha Allah.

"Ketika anda sangat dekat dengan seseorang, maka intuisi anda pada orang tersebut akan sangat tajam dan cepat" (halaman 69). Dalam mengatur kedekatan kita dengan sesama manusia, maka kita harus saling memperhatikan dan saling peduli karena pada dasarnya setiap manusia adalah makhluk sosial yang tidak dapat hidup sendiri.

"Tetaplah bersikap rendah hati, sederbana, dan dermawan" (halaman 81). "Ketika anda menudub oranglain Riya" (halaman 109). Kalimat diatas mengajak kita agar senantiasa menghindarkan diri dari prilaku Suudzan karena hanya akan menimbulkan perpecahan dan kedengkian serta mendatangkan penyakit hati lainnya dan sama sekali tidak ada manfaatnya.

\section{3) Akhlak Kepada Lingkungan}

Dasar hukumnya terdapat dalam QS. Al A'raf ayat 56:

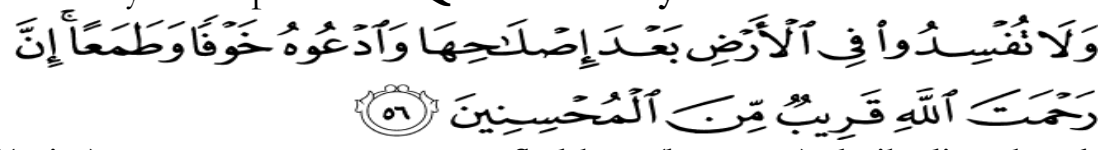

"(yaitu) orang-orang yang menafkahkan (hartanya), baik di waktu lapang maupun sempit, dan orang-orang yang menahan amarahnya dan memaafkan (kesalahan) orang. Allah menyukai orang-orang yang berbuat kebajikan.” (Kementerian Agama Republik Indonesia, Al-Qur'an Terjemahan, Mushaf Al-Tasdiiq. Bandung: Tasdiqiya Publisher : 2010). 
Pesan akhlak kepada lingkungan dalam Buku 7 Keajaiban Rezeki terdapat pada kalimat-kalimat sebagai berikut "Ajaklah orang-orang disekitar anda untuk. mengasah otak kanan" (halaman 74). Dari kalimat diatas, penulis mengajak kita agar senantiasa peduli terhadap orang lain, termasuk saat kita mendapatkan rezeki dan memiliki ilmu maka kita harus berbagi terhadap sesama, baik manusia maupun lingkungan.

\section{c. Pesan Syariah}

1) Ibadah

Dasar hukumnya terdapat dalam QS. Al-Bayyinah ayat 5:

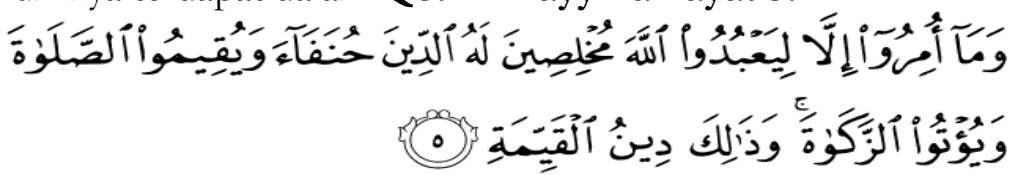

"Padahal mereka tidak disuruh kecuali supaya menyembah Allah dengan memurnikan ketaatan kepada-Nya dalam (menjalankan) agama yang lurus, dan supaya mereka mendirikan shalat dan menunaikan zakat; dan yang demikian itulah agama yang lurus" (Kementerian Agama Republik Indonesia, Al-Qur'an Terjemahan, Mushaf Al-Tasdiiq. Bandung: Tasdiqiya Publisher : 2010).

Pesan ibadah dalam Buku 7 Keajaiban Rezeki terdapat pada kalimatkalimat sebagai berikut "Tbadah dan Sedekah cara Otak Kanan", "Tbadah dan Sedekah cara Otak Kiri" (halaman 60-62). "Bersedekablah sekurang-kurangnya 10\% dari biaya berobat dan dokter" (halaman 64). "Bisnis Modal dengkul (Bersimpuh) dan modal Jidat (Bersujud) dengan Allab" (halaman 70). Secara keseluruhan, kalimat-kalimat diatas berupa saran dan ajakan kepada pembaca agar melaksanakan beberapa ibadah yang mudah dilakukan dan memiliki keutamaan-keutamaan yang mampu meninggikan derajat kita dimata Allah serta dapat memperbaiki rezeki kita tentunya.

\section{2) Muamalah}

Dasar hukumnya terdapat dalam QS. Ali Imran ayat 130:

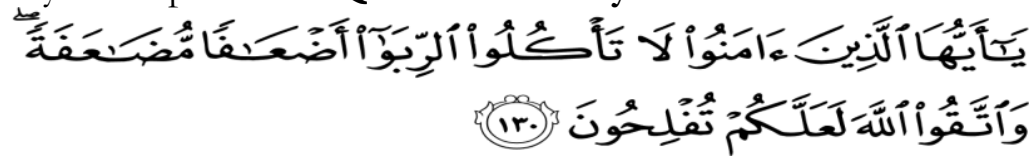

"Hai orang-orang yang beriman, janganlah kamu memakan riba dengan berlipat ganda] dan bertakwalah kamu kepada Allah supaya kamu mendapat keberuntungan." (Kementerian Agama Republik Indonesia, AlQur'an Terjemahan, Mushaf Al-Tasdiiq. Bandung: Tasdiqiya Publisher : 2010). 
Pesan Muamalah dalam Buku 7 Keajaiban Rezeki terdapat pada kalimatkalimat sebagai berikut "Tabukah anda, begitu impian orang-orang disekitar anda selaras dengan impian anda, berarti impian anda menjadi lebih bersayap. Dan impian anda menjadi lebib cepat terwujud. Sangat Cepat!" (halaman 29). Dalam kalimat diatas, pesan muamalahnya sangat erat kaitannya dengan kemaslahatan bersama, bahwa setiap orang disekeliling kita adalah orang-orang yang sangat berpengaruh bagi kita. Mereka bisa memberikan doa yang baik bahkan yang buruk, mka dari itu berbaiklah dengan lingkungan sekitar maka kebaikanpun akan hinggp pda diri kita.

"Berbisnislah dengan bisnis yang melayani jutaan dan ribuan orang." Mengapa harus berbisnis yang melayani banyak orang? Pada dasarnya inti dari kehidupan ini adalah kebermanfaatan, dalam seluruh elemen kehidupan, baiknya apa yang kita lakukan dan apa yang kita kerjakan harus bermanfaat bagi kehidupan orang banyak agar kehidupan kita menjadi lebih berkah.

\section{PENUTUP}

Dakwah bil Qalam termasuk kedalam klasifikasi media dakwah yang terus mengalami metamorfosis dari masa ke masa, bermula dari media cetak lalu terus mengalami perubahan dan pembaharuan mengikuti perkembangan zaman. Seiring dengan kemajuan Internet sebagai media komunikasi, muncul media sosial yang turut mengiringinya, maka dari itu perlu adanya optimalisasi penggunaan dakwah bil qalam oleh para praktisi dakwah dengan meningkatkan kemampuan ICT (Internet, Communication, Technology) dan teknik menulis naskah dakwah di media, dengan begitu diharapkan para praktisi dakwah mampu mengisi rubrik-rubrik di media cetak koran, majalah dan sosial media dengan konten dakwah yang lebih modern, kreatif dan inovatif.

Buku sebagai salah satu karya tulis cetak yang paling tua juga tidak boleh luput dari perhatian para praktisi dakwah sebagai media tulisan yang relevan serta memiliki rekam jejak yang dapat dilacak, diantara kelebihan lainnya dari media tulisan buku ini sangat komprehensif untuk dijadikan sumber rujukan penelitian, dapat disimpan dan diarsipkan untuk dibuka lagi dikemudian hari. Media dakwah melalui tulisan berupa literatur buku ini juga sangat cocok untuk strategi perkembangan dakwah islam karena dapat membuka wawasan masyarakat agar lebih memperhatikan rujukan sumber materi dakwah.

Pembahasan dalam buku 7 Keajaiban Rezeki yang merupakan bagian dari aspek kognisi tulisan untuk diterapkan kedalam kehidupan, seperti senantiasa beribadah, bershalawat dan berdzikir tanpa ada sebab-sebab apapun dan hitungan-hitungan tertentu. Dalam buku tersebut juga ingin menerapkan pemahaman tentang menerapkan akidah, akhlak, dan syariah yang dibahas secara ringan dan disertai dengan contoh sehingga masyarakat dapat memahami pesan 
simbolik dan komunikasi yang ingin dikemukakan oleh penulis. Kontruksi pesan dakwah pada buku 7 Keajaiban Rezeki diklasifikasikan kedalam 3 jenis yaitu pesan Informatif yang berupa informasi bagi pembaca yang sesuai dengan data, Persuasif yang berupa ajakan secara halus dan menarik, dan koersif berupa ajakan yang agak memaksa dan memiliki maksud tertentu agar pembaca sepakat dan mengikuti keinginan penulis, biasanya pesan koersif ini disertai dengan sebab dan akibat untuk menimbulkan ketakutan pada pembaca.

Masyarakat juga dianjurkan untuk lebih kritis terhadap berbagai ideologi yang ada dalam berbagai media informasi dan masyarakat harus lebih cerdas memfilter sumber-sumber ajaran keagamaan yang tidak sesuai dengan Al-Qur'an, Hadits dan kebiasaan di masyarakat. Disamping itu, munculnya media dakwah baru yang lebih efisien digunakan seperti sosial media, harus mampu memacu keinginan dakwah dari setiap individu masyarakat, setiap orang dapat berdakwah dengan adanya media sosial tersebut dengan mengisi kolom-kolom status, caption, dan kolom komentar dengan obrolan-obrolan bermuatan dakwah islam. Dengan begitu, dakwah islam dapat menyebar keseluruh lapisan masyarakat, menjadi perbincangan yang positif dan diharapkan dalam jangka panjang mampu mengakar dalam kehidupan masyarakat untuk selalu Amar Makruf Nabyi Munkar demi terciptanya masyarakat yang islami yaitu masyarakat yang beriman, berilmu, dan beramal shaleh.

\section{DAFTAR PUSTAKA}

Aripudin, A. (2013). Sosiologi Dakwah, Bandung, Rosdakarya.

Arifin, M. (2004). Psikologi Dakwab: Suatu Pengantar Studi. Jakarta: PT

Bumi Aksara.

Badara, A. (2012). Analisis Wacana Teori, metode, dan Penerapannya pada

Wacana Media. Jakarta: Kencana Prenada Media Group.

Darma Yoce, A. (2014). Analisis W acana Kritis. Bandung: PT. Refika Aditama.

Eriyanto. Analisis Teks Media. Yogyakarta. LKIS.

Enjang AS, Aliyudin. (2009). Dasar-dasar Ilmu Dakwah. Bandung: Widya

Padjajaran, Cetakan Juni 2009. ISBN 978-602-8323-34-5.

Fachruroji, M. (2017). Dakwah di Era Media Baru, Bandung, Simbiosa

Rekatama Media.

Haryatmoko. (2017). Critical Discourse Analysis (Analisis Wacana Kritis)

Landasan Teori, Metodologi, dan Penerapan. Jakarta: Raja Grafindo

Persada.

Ichtiar Baru Van Hoeve; Hassan Shadily. (1998) Ensiklopedia Indonesia, Jilid 7. Jakarta: PT Ichtiar Baru Van Hoeve.

Kementerian Agama Republik Indonesia. (2010) Al-Qur'an Terjemahan, Mushaf Al Tasdiiq. Bandung: Tasdiqiya Publisher. 
Munir Mulkan, A. (1993). Paradigma Intelektual Muslim, Yogyakarta, Sipress.

Kusnawan, A. (2016). Teknik Menulis Dakwah. Bandung: Simbiosa Rekatama Media. ISBN 978-602-7973-44-2.

Kusnadi, A. (2004) Ilmu Dakwah (Kajian Berbagai Aspek), Pustaka Bani

Quraisy,Bandung.

Muhyiddin, A. dkk. (2014). Kajian Dakwah Multiperfektif, Teori Metodologi Problem dan Aplikasi. Bandung: Remaja Rosdakarya.

Munir, M. Ilaihi, W. (2009). Manajemen Dakwah, Jakarta : Kencana Prenada

Media Group, Cetakan II.

Munir Amin, S. (2008). Kontruksi Pemikiran Dakwah Islam, Jakarta:

Amzah

Santosa, I. (2012). 7 Keajaiban Rezeki, Rezeki Bertambah Nasib Berubah dalam 99 Hari dengan Otak Kanan, PT Alex Media Komputindo, Kelompok Gramedia,Cetakan ke-21.

Santosa, I. (2011) Percepatan Rezeki 40 Hari dengan Otak Kanan, PT Alex Media Komputindo, Kelompok Gramedia, Cetakan Ke-21.

Schiffrin, D. (1994). Approaches to Discourse. Oxford: Blackwell.

Van, Dijk Teun A. (1993). Principles of critical discourse analysis. Discourse \& Society.

Yakub, H. (1981). Publisistik Islam: Teknik Dakwah dan Lidership.

Bandung: CV. Diponegoro.

Aliyudin. (2010). Prinsip-prinsip Metode Dakwah Menurut Al-Qur'an. Jurnal Ilmu Dakwah. Vol.4, No. 15 Januari-Juni 2010.

Enjang AS. (2008). Dakwah Smart: Proses Dakwah Sesuai Dengan Aspek

Psikologi Mad'u. Jurnal Ilmu Dakwah. Vol.4, No.12 Juli-Desember 2008.

Kusnawan, A. (2009). Creative Writting Club Sistem Swa-Mandiri Pelatihan Menulis. Jurnal Ilmu Dakwah. Vol.4, No.13 Januari-Juni 2009.

Rasid, A. (2008). Freedom Of The Speech (Dimensi Kebebasan Dalam Paradigma Komunikasi Dakwah). Ilmu Dakwah: Academic Journal For Homiletic Studies. Vol. 4, No.11 Januari-Juni 2008. ISSN 67-88.

Ridwan, A. (2011). Ragam Khitobah Ta'siriyah, Sebuah Telaah Ontologis. Jurnal Ilmu Dakwah. Vol.5, No.17 Januari-Juni 2011.

Saepuloh, U. (2009). Model Komunikasi Dakwah Jamaah Tabligh. Jurnal Imu Dakwah. Vol.4, No.14 Juli-Desember 2009.

Sarbini, A. (2010). Paradigma Baru Pemikiran Dakwah Islam. Jurnal Ilmu Dakwah. Vol.4, No.15 Januari-Juni 2010.

Shodiqin, A. (2012). Reposisi Muballigh: Dari 'Personal' Menuju 'Agent of Change'. Ilmu Dakwah: Academic Journal For Homiletic Studies. Vol. 6, No.2 Desember 2012. ISSN 1693-0843. 
Sukayat, T. (2012). Revitalisasi Ilmu Dakwah: Kajian Mabadi ‘Asrah Ilmu Dakwah. Ilmu Dakwab: Academic Journal For Homiletic Studies. Vol.6, No.2 Desember 2012. 195-206 ISSN 1693-0843

Al-Qur'an dan Terjemahan, http://tafsir.com diakses pada Desember 2018.

Fanpage Facebook 7 Kejaiban Rezeki. Diakses pada 12 Desember 2018.Website of Teun A. Van Dijk. Diakses pada 09.03 WIB, 03 Januari 2019.

Ridwan, A. (2016): Mentoring Penataran Calon Da’i, Lingkar Barudak Khitobah. Komunikasi dan Penyiaran Islam, UIN Sunan Gunung Djati: Bandung. 